\title{
Cultura de queratinócitos lamelares de equinos
}

João Pedro Hübbe Pfeifer ${ }^{[a]}$, Vitor Hugo Santos, Gustavo dos Santos Rosa ${ }^{[a]}$, Betsabéia Heloísa Gentilha Milani[a], Jaqueline Brandão de Souza ${ }^{[a]}$,Andre Massahiro Teramoto Krieck ${ }^{[a]}$, Elenice Deffune ${ }^{[b]}$,Ana Liz Garcia Alves ${ }^{[a]}$

\footnotetext{
[a] Faculdade de Medicina Veterinária e Zootecnia, Universidade Estadual Paulista (UNESP), Botucatu, SP, Brasil

${ }^{[b]}$ Faculdade de Medicina, Universidade Estadual Paulista (UNESP), Botucatu, SP, Brasil
}

*Autor correspondente

e-mail: pfeifer@fmvz.unesp.br

\section{Resumo}

Laminite é uma enfermidade grave que atinge os equinos, inicialmente com alterações na circulação digital, seguido por reação hiperêmica e lesões de reperfusão que resultam na perda do estojo córneo (casco) devido à hipóxia e consequente necrose do tecido laminar, o que muitas vezes resulta em eutanásia destes animais. Um dos principais fatores de lesão laminar é a alteração do citoesqueleto dos queratinócitos, devido à diminuição de hemidesmossomos nas células epiteliais da lâmina basal, evidenciada no início da claudicação. A progressão das alterações histopatológicas na região lamelar do casco, em derme e epiderme, quando a matriz do casco não está envolvida, as alterações restringem-se à epiderme. Este trabalho realizou a cultura de queratinócitos provenientes de lâminas epidermais de casco equino, a fim de padronizar a cultura de células hígidas, para uma posterior análise da cultura de células provenientes de equinos que apresentem laminite. Foram realizadas 22 culturas de amostras em cultivos primários bidimensionais, sendo avaliadas pelo método de explantes, comparando dois meios de cultura. Ao $10^{\circ}$ dia de cultura foi realizada a retirada dos explantes, procedendo com a passagem (troca da placa onde as amostras são cultivadas) das culturas onde as células foram analisadas em diferentes formas de subculturas tridimensionais (3D), em placa de poços com substrato de cola de fibrina e placa comercial de poços com insertos de membrana de colágeno. As células foram cultivadas até a segunda passagem, apresentando morfologia cubóide/ovalada - característica dos queratinócitos - e proliferação celular atingindo 80\% de confluência. Com relação aos meios de culturas testados, não foi evidenciada nenhuma diferença entre as culturas. As células que foram cultivadas em placa de inserto comercial tiveram melhor expansão do que aquelas cultivadas em cola de fibrina, possivelmente devido à espessura do substrato de cola de fibrina. Com isso, verificamos que a cultura de queratinócitos de casco equino através de explantes é uma técnica viável, e com adequações é possível realizar a subcultura 
nos dois substratos avaliados, tornando a pesquisa in vitro de queratinócitos de casco equino uma potencial ferramenta para verificar a eficiência da terapia regenerativa na laminite equina.

Palavras-chave: Cultura celular. Equinos. Lâminas epidermais. 